\title{
Papillary Transitional Cell Carcinoma
}

National Cancer Institute

\section{Source}

National Cancer Institute. Papillary Transitional Cell Carcinoma. NCI Thesaurus. Code C4122.

A non-invasive or invasive transitional cell carcinoma characterized by a papillary growth pattern. It may occur in the bladder or the renal pelvis. 